\title{
Factors Affecting Oilseed Quality during Storage with Special Reference to Soybean (Glycine max) and Niger (Guizotia abyssinica) Seeds
}

\author{
Jaya Singh $^{1 *}$, Seema Paroha ${ }^{2}$ and Ravi Prakash Mishra ${ }^{1}$ \\ ${ }^{1}$ Department of P.G. Studies and Research in Biological Sciences, \\ Rani Durgavati University, Jabalpur-482001, India \\ ${ }^{2}$ Biochemistry Laboratory, Project Co-ordination Unit, All India Coordination Project (Sesame \\ and Niger), Jawaharlal Nehru Krishi Vishwavidyalaya, Jabalpur-482004, India \\ *Corresponding author
}

\section{A B S T R A C T}

\begin{tabular}{|l|}
\hline Ke y w or d s \\
Oilseeds, Storage, \\
seed vigor, \\
Soybean, Glycine \\
max, Niger, \\
Guizotia abyssinica. \\
\hline Article Info \\
\hline Accepted: \\
21 September 2017 \\
Available Online: \\
10 October 2017 \\
\hline
\end{tabular}

Seed storage is a vital and very important process for agriculture, as it not only protects seeds for the next season for the plantation purpose but also maintain seed quality for the commercial purposes. Among the oilseed crops grown in India, soybean (Glycine max) and niger (Guizotia abyssinica) has of late emerged as having high growth potential. One of the major problems associated with the seed production of soybean and niger in India, is the maintenance of the seed viability up to the prescribed germination standard from harvest till next sowing season. Oilseeds are some of the important agricultural produce that are commercially viable and hence need proper care and handling of seeds during storage. The present review highlights some of the key parameters that affect the storability of oil seeds especially soybean and niger.

\section{Introduction}

Oilseeds and edible oils are two of the most sensitive essential commodities. Oilseeds are important sources of edible oils of nutritional, industrial, and pharmaceutical importance. Groundnut, mustard/rapeseed, sesame, safflower, linseed, niger seed, castor are the major traditionally cultivated oilseeds. Soybean and sunflower have gained high importance in recent years, while coconut is most important amongst the plantation crops ${ }^{1}$.

The field performance of seed lot is dependent on its quality. Two attributes of seed quality that are often measured are seed viability and vigor ${ }^{2}$. The viability of a seed refers to its ability to germinate and produce a normal seedling ${ }^{3}$. Viability also refers to the degree to which a seed is metabolically active and contains enzymes capable of catalyzing the reactions needed for germination and seedling growth. Vigor is defined as those seed properties, which determine the potential for rapid, uniform emergence and development of normal seedlings under a wide range of field conditions ${ }^{4}$.

Soybean is a species of legume native to East Asia, widely grown for its edible bean which 
has numerous uses. The plant, classed as an oilseed rather than a pulse by the UN Food and Agriculture Organization, produces significantly more protein per acre than most other uses of land. Together, protein and soybean oil content account for $56 \%$ of dry soybeans by weight (36\% protein and $20 \%$ fat). The remainder consists of $30 \%$ carbohydrates, 9\% water and 5\% ash). Soybeans comprise approximately $8 \%$ seed coat or hull, $90 \%$ cotyledons and $2 \%$ hypocotyl axis or germ. Raw soybeans are $20 \%$ fat, including saturated fat (3\%), monounsaturated fat (4\%) and polyunsaturated fat, mainly as linoleic acid. Within soybean oil or the lipid portion of the seed is contained four phytosterols: stigmasterol, sitosterol, campesterol, and brassicasterol accounting for about $2.5 \%$ of the lipid fraction; and which can be converted into steroid hormones ${ }^{4}$.

Niger (Guizotia abyssinica) is an oil yielding plant native to Ethiopia and Malawi ${ }^{5}$, and a marginal oilseed crop of Central India, especially of Madhya Pradesh ${ }^{6}$. Niger is one of the important oilseed crop in the Madhya Pradesh, it is the life line of the tribes and cultivated mainly by marginal farmers in marginal conditions. Niger seed resembles sunflower seeds in shape, but is smaller in size and black, bears a fairly thick, adherent seed coat and contains good amounts of proteins, oil and soluble sugars. Niger seed has high oil content (30-35\%). The seed oil is clear, edible and polyunsaturated oil with a nutty taste and sweet odor. Raw oil has low acidity and can be used directly for cooking with fatty acid composition similar to sunflower oil and has high content of linoleic $\operatorname{acid}^{7}$.

\section{Seed storability}

Soybean seed is reported to have a poor viability and field emergence as compared to other kharif oil seed/pulse crops due to its inherent seed structure and composition ${ }^{8}$. On the other hand, niger is less studied and less cultivated oilseed. Keeping this in mind, the study of seed storability and the effect of various factors is of great importance. Since, these two oilseeds have great economical value, the storability can be understood in the perspectives of germination as well as oil content and quality.

Seed storability is defined as the longevity of seeds after storage. During storage, seed quality is affected by several factors like environmental conditions during seed production, pests, diseases, seed oil content, seed moisture content, mechanical damages of seed during processing, packaging materials, pesticides, air temperature and relative air humidity in storage $9,10,11,12$.

Seed storability is especially important in the tropics due to high temperature and relative humidity of storage environment that cause rapid deterioration of seeds in storage. The two most important environmental factors that influence seed storage life are relative humidity, which controls seed moisture content; and temperature, which affects the rate of biochemical processes in seeds ${ }^{13}$. The effects of relative humidity and temperature on storage environment are highly interdependent.

\section{Physical factors affecting seed quality during storage}

Many factors determine the longevity of seeds during storage. These includes seed moisture content, temperature, relative humidity, initial viability, stage of maturity at harvest, storage gas and initial moisture content of seed entering into storage ${ }^{14}$. High relative humidity increases seed moisture content, leading to biochemical events such as increased hydrolytic enzyme activity, enhanced respiration and increase in free fatty acids. High temperature elevates rates of many 
enzymatic and metabolic reactions, causing more rapid deterioration.

High temperatures fasten deterioration of high moisture seeds by increasing metabolic activity of hydrolysed substrates and enzymes, but exert only a minimal deteriorative effect on low moisture seeds ${ }^{13}$. A humid tropical climate characterized by high temperature and high relative humidity is very conducive to rapid deterioration of soybean seeds in storage, causing reduction in vigour and viability, leading to poor germination and suboptimal plant stand. Moreover, soybean is classified in the least storable group in their relative storability index ${ }^{15}$.

The relative humidity $(\mathrm{RH})$ of a storage environment, therefore, directly influences the moisture content of the seed ${ }^{16 .}$ The $\mathrm{RH}$ at which physiological changes occur within the seed was similar for most orthodox species ${ }^{17}$.

The moisture content of the seed that is in equilibrium with RH of between 19 and $27 \%$ was defined as the optimum for storage ${ }^{17}$. However, Ellis et al., ${ }^{18}$ proposed that seeds should be dried to moisture contents in equilibrium with a $\mathrm{RH}$ in equilibrium with $11 \%$ moisture content at a temperature of 20 ${ }^{\circ} \mathrm{C}$. The moisture content at this $\mathrm{RH}$ was defined as the critical moisture content of a seed lot below which the viability equation was not applicable.

Temperature has a significant effect on the thermodynamic properties of seed systems ${ }^{17}$. At constant relative humidity, an increase in temperature causes an increase in water activity. High temperatures accelerate the rate of peroxidation of lipids and the absence of oxygen can inhibit the process.

The problems of maintaining the soybean seed viability in storage have always been an important concern; and retention of high viability over a long period is necessary for crop production. Soybean seed decline in quality faster than seeds of other crops. It has been reported that the short life span of soybean in storage could be due to certain factors including the high oil content and perhaps high moisture content. One of the major constraints to the production of soybean in the tropics is the rapid loss of seed viability and vigour during storage under ambient conditions. The loss of germination is much more acute under tropical conditions ${ }^{19}$.

Farmers in the developing world, including India, still store their produce including seed under the ambient environment. The storage under ambient conditions has been observed to affect seed quality in general and germination in particular. Storage is however, improved under ambient conditions if seeds are well-packaged ${ }^{20}$.

Mbofung et al., ${ }^{21}$ determined the best storage environments that would minimize deterioration of soybean seed. Twentyfour soybean varieties, different in lipid and protein contents were stored in three storage environments differing in temperature and relative humidity: a cold storage $\left(10^{\circ} \mathrm{C}\right)$, a warm storage $\left(25^{\circ} \mathrm{C}\right)$, and a warehouse. Seed viability remained high throughout the study for seeds stored in cold storage (>92\%) and moderate in the warm storage $(>78 \%)$ but decreased to almost $0 \%$ after 20 months in the warehouse. Seed vigor was affected by only seed lipid content for seeds stored for 12 months, regardless of storage environment.

Ali et al., ${ }^{22}$ found out the effect of storage relative humidity, seed moisture content and type of storage container on soybean seed quality in a completely randomized design. The seeds from 2008 harvest $(96 \%$ initial germination) and from 2009 (98\% initial germination) were stored at $8 \%$ and $12 \%$ initial moisture levels in two types of storage containers viz., cloth bag and polythene bag. 
Highest germination percentage of soybean seeds was retained at 180 days after storage for those stored at $8 \%$ initial seed moisture content in polythene bag at $50 \%$ relative humidity. Germination index and seedling dry matter decreased with increased initial seed moisture content irrespective of storage containers used. Those stored in cloth bag at $12 \%$ moisture showed rapid germination loss and the value went down to 0.00 in both the years.

We have also shown the effect of storage period on seed vigour and germination of soybean and niger, two oil seeds from Central India. The seeds were stored for a period of 07 years in polythene bags under ambient conditions. The soybean seeds showed loss of moisture after storage period of two years or more, while niger seeds did not show significant loss of moisture content upto seven years. Soybean seeds showed significant increase in electrical conductivity $\left(172.2 \pm 4.1 \mu \mathrm{S} \mathrm{cm}^{-1} \mathrm{~g}^{-1}\right.$ for 0 year to $470.34 \pm$ $4.8 \mu \mathrm{S} \mathrm{cm}^{-1} \mathrm{~g}^{-1}$ for 6 years) showing seed deterioration as compared to niger seeds (1.56 $\pm 0.07 \mu \mathrm{S} \mathrm{cm}^{-1} \mathrm{~g}^{-1}$ for 0 day to $6.44 \pm 1.1 \mu \mathrm{S}$ $\mathrm{cm}^{-1} \mathrm{~g}^{-1}$ for 6 years). The soybean seeds stored for mid-term storage showed $0-15 \%$ germination while for short term stored seeds, the germination percentage was $40-70 \%$. The niger seeds showed $40-60 \%$ germination for mid-term stored seeds and upto $100 \%$ germination for short term stored seeds. The tetrazolium test showed higher numbers of viable seeds in niger as compared to soybean. The study indicates that niger seeds have better storability than soybean seeds under ambient conditions ${ }^{23}$.

\section{Chemical factors affecting the seed storability}

The chemical composition of oilseeds causes specific processes to occur during storage. The seeds rich in lipids have limited longevity due to their specific chemical composition. For example, sunflower seed storage demands special attention due to high oil content, otherwise processes may occur that lead to loss of germination ability and seed viability $^{24,25}$.

The development of rancidity has been recognized as the predominant cause of oil deterioration and reduction during storage ${ }^{26}$. Due to the presence of double bonds in unsaturated fatty acids these fatty acids are susceptible to oxidation, which is a reaction between unsaturated fatty acids (regardless of whether they are in their free state or esterified in a triaglycerol molecule) and oxygen. It is well known that the rate of oxidation increases with the increase in oxygen concentration and the duration of exposure (the length of storage time). The oxidation of oil requires the presence of atmospheric oxygen. The longer the storage time the higher the oxygen availability and vice versa.

According to Sisman et al., ${ }^{27,28}$ during storage period the oil content of sunflower (Heliantus annus) decreased progressively. They reported that increase in temperature and humidity caused to spoil of oil and increasing of free fatty acid. Martini and Anon ${ }^{29}$ reported that during storage of sunflower seed in different temperature the oil content did not influence. It seems temperature; moisture and the storage duration are the most important factors which influence on stored product quality and quantity.

The mature soybean seed is made of very few proteins. The bulk of the soybean storage proteins are the salt-soluble globulins, $\beta$ conglycinin and glycinin ${ }^{30}$. Together, these soybean storage proteins account for about $70 \%$ of the total protein content in the seed. Most of the functional proteins are stressrelated proteins. For example, the heat shock 
proteins protect against heat stress, while the late embryogenesis abundant proteins play a role in seed desiccation tolerance and membrane stability ${ }^{31}$.

Twenty percent of the dry weight of soybean seed is made up of oil ${ }^{32}$. The soybean seed contains 14 fatty acids mainly palmitic (C16: 0), stearic (C18: 0), oleic (C18: 1), linoleic (C18: 2), and linolenic (C18: 3). The percentage of these five fatty acids in soybean oil averages 10\%, 4\%, 18\%, 55\%, and 13\%, respectively $^{32}$. Sixteen percent of the total fatty acid is saturated while $84 \%$ is unsaturated. This fatty acid profile results in low oxidative coefficients, which are considered partly responsible for its poor storability. Vertucci and Roos ${ }^{18}$ observed that the moisture content at which physiological processes change within the seed was highly correlated with the lipid content of the seed. High lipid seeds had lower thresholds for respiration and required lower moisture contents for optimum storage. Oil content also appeared to have a strong correlation with absolute longevity of soybean seeds under open storage conditions ${ }^{33}$.

Oxidative reactions that occur within stored seeds are considered to be, in part, responsible for seed deterioration. The rate of oxygen uptake in soybean is very strongly correlated with the seed moisture content. Seeds with high moisture content $(\geq 24 \%$ ) had a higher respiratory quotient than those with lower moisture content $(\leq 24 \%)^{34}$. At very low moisture contents of 0.10 and $0.24 \mathrm{~g} \mathrm{H}_{2} \mathrm{O} / \mathrm{g}$ seed at which respiratory processes are imperceptible in other seeds, low levels of respiration in the soybean seed has been found. Evidence that aging in soybean is induced by accumulation of respiratory byproducts was observed in aged seeds in which there was a decrease in oxygen consumption due to mitochondria injury ${ }^{35}$. Other observable effect of aging in the mitochondrion was the reduction of the rate of conversion of AMP and ADP to ATP in deteriorated axes of soybean ${ }^{35}$.

The consequences of respiration at all moisture contents is the peroxidation of membrane unsaturated lipids. Lipid peroxidation can be non-enzymatic (autoperoxidation) or enzymatic (by lipooxygenase) and both processes result in seed aging ${ }^{33}$. Autoperoxidation is initiated by oxygen around unsaturated or polyunsaturated fatty acids such as linoleic and linolenic acids found commonly in seed membranes and storage oils $^{13}$.

In intact seeds, autoperoxidation usually starts in the mitochondria polar lipids of the embryonic axes. This results in the formation of free radicals that are propagated to other membranes within the seed. Lipid peroxidation occurs in all cells, but in fully imbibed cells, water acts as a buffer between the free radicals generated by autoxidation and the target macromolecules, thereby reducing damage.

According to Nagel and Börner ${ }^{33}$ the chemical composition of the seed affects its sorption properties; the available potential sites for free radical attack and the presence and activity of protective compounds within the seed. In addition to their low threshold for respiration, soybeans have high levels of polyunsaturated fatty acids. The consequence of peroxidation of polyunsaturated fatty acids of the seed membranes is the destabilization of the membranes, which leads to uncontrolled leakage of solutes. In addition, damage to the mitochondria results in decreased oxygen consumption and low levels of oxidative phosphorylation ${ }^{35}$. Soybean seeds stored at $4^{\circ} \mathrm{C}$ and at low humidity for 44 months showed a marked decline in vigor associated with a decrease in the proportion of unsaturated fatty acids ${ }^{36}$. 
Studies in several species such as soybean (Glycine max), maize (Zea mays), and brassica (Brassica campestris) have suggested that oligosaccharides might be involved in the protection of seeds against damage during seed dehydration and aging, and therefore in seed survival and storability ${ }^{37}$. oligosaccharides have been speculated to be involved in the protection of membranes, proteins, and nucleic acids against damage that occurs during and upon the withdrawal of water in the drying seeds ${ }^{38}$.

Other by-products of the seed aging process that can lead to seed deterioration are the Amodori and Maillard products. The Amodori and Maillard products are the result of sugar hydrolysis and lipid peroxidation coupled with nonenzymatic protein modification $^{39}$. Amadori reactions lead to the chemical modification of proteins by reducing sugars to form fructosyl derivatives, or glycosylated proteins within the seed during storage. This process gradually reduces the ability to limit free radical damage and hinders the repair of damage during seed germination ${ }^{39,40}$. Maillard products are formed through subsequent complex interactions between glycosylated Amadori products to form polymeric brown colored products. Maillard products were observed in naturally aged soybean seeds and were associated with the loss of seed viability under long term storage conditions ${ }^{40}$.

Soybean seeds contain a complex system of antioxidants to protect against the harmful consequences of reactive oxygen species. These include the free-radical scavengers such as superoxide dismutase, catalase, ascorbate peroxide, peroxidase, and tocopherols. The location of some of these compounds in the seed is an indication of the importance of their role as reactive oxygen species scavengers in the seed. Storage lipid bodies forms about $90 \%$ of the cellular lipid in soybean seeds and are associated with the great majority of tocopherols. Tocopherol contents in soybean seeds were shown to decline after accelerated aging suggesting it was consumed to protect the seed against free radicals. Superoxide dismutase is believed to be synthesized de novo by the seed during imbibition $^{41}$.

Degradation of phospholipids and structural deterioration of biological membranes have been suggested to be particularly significant issues during ageing in soybean seeds ${ }^{42}$. When $\mathrm{Ca}^{2+}$ is added to young bean cotyledons, the action of phospholipase $\mathrm{D}$ and phosphatidic acid phosphatase can induce lipid breakdown in smooth microsomal membranes ${ }^{43}$. Duxbury et al., ${ }^{43}$ suggested that degradation of the phospholipid bilayer during natural ageing of soybean cotyledons, facilitated by lipolytic enzymes, stimulates loss of protein function and proteolysis. In natural ageing of seeds, the loss of seed vigour and germination ability is also coincident with increased electrolyte leakage. Moreover, changes in lipid composition, including oxidation and peroxidation, can lead to loss of the economic and nutritional value of soybean seed through modifications in colour, taste, odour and viability during shipment and storage.

Ghasemnezhada and Honermeierb ${ }^{44}$ clarified the storage able potency of high and low oleic cultivars of sunflower based on oil and fatty acid changes of seeds and their viability. The seed samples of four sunflower cultivars (two high oleic and two low oleic) were stored in three different temperature conditions $\left(4-5^{\circ} \mathrm{C}\right.$, 21-22 ${ }^{\circ} \mathrm{C}$, and $35^{\circ} \mathrm{C}$ ) in a period of four months. Results show that quality parameters of seeds such as oil content, fatty acid composition and protein content were significantly influenced by storage conditions in most cases. In all experimental cultivars oil content was significantly influenced by storage time. Indeed, the longer storage times the higher oil reduction and vice versa. In 
most cases the oleic acid reduced as storage time progressed. Free fatty acid content of crude oil increased in longer storage time and higher temperature.

De Oliveira Lins et al., ${ }^{45}$ investigated changes in sunflower seed physiology, health, structural quality, and oil quantity and distribution, under storage at different temperatures and packaging conditions. Germination, seedling emergence, accelerated aging, electrical conductivity, potassium leaching, and seed health tests were performed before storage and at 4, 8, and 12 months of storage. In addition, the water content, oil content, and enzymatic activities were determined. The seed response to storage varied with time, packaging material, and temperature. The physiological quality of the sunflower seeds was best preserved at $10^{\circ} \mathrm{C}$ in Kraft paper bags packaging material. Aspergillus sp. and Penicillium sp. occurred regardless of storage conditions. In addition, the seed oil concentrations decreased with time regardless of storage conditions. However, the fatty acid profile remained the same. At four months, the superoxide dismutase, catalase, alcohol dehydrogenase, and malate dismutase activities decreased regardless of storage conditions. This decrease was more obvious in the vacuumsealed seeds. In addition, the cellular components of the sunflower seeds deteriorated during the storage period.

\section{Effects of pathogens on seed storability}

Pathogens found on or in seeds that could potentially be transmitted to a subsequent crop can adversely affect germination and vigor, emergence and seedling vigor. The level of infection of the seed determines the degree to which the seedling is affected. Diseased plants in the field produce shrunken seeds and often times smaller seeds that have reduced germination potentials and low vigor $^{46}$. Fungi commonly referred to as storage molds are fewer than $10 \%$ and belong to the genera of Chaetomium sp., Rhizopus, Mucor, Aspergillus and Penicillium spp and increase during storage ${ }^{47}$.

The temperature and $\mathrm{RH}$ of the storage environment can greatly influence the infection rate, growth and development of the fungal pathogens on the seed. Infection rate of soybean seeds with Diaporthe phaseolorum (Cooke Ellis) Sacc. var. sojae was significantly lowered after 2 years of storage in a dry and cool environment ${ }^{48}$.

The storage of oilseeds under marginal conditions is highly affected by storage fungi. In oilseed crops the seed mycoflora are known to affect the quality and quantity of the oil. Siddaramiah et al., ${ }^{49}$ reported Aspergillus niger, A. flavus, Alternaria alternata, Alternaria sp., Rhizopus nigricans, Rhizoctonia bataticola and septate sterile fungal mycelium to be associated with the niger seeds.

Niger seeds were found to be infected mainly by Actinomycetes in all types of containers throughout the storage period. Maximum infection was observed in plastic containers while in gunny bags and baked earthen pitchers it was comparatively low. Besides Actinomycetes, five species of fungi were also found to infect stored niger seeds. Among these species, Chaetomium was predominant and it was of more or less of regular occurrence $^{50}$. It was also observed that there was no decrease in germination of niger seeds when stored in gunny bags and baked earthen pitchers (with 6 and $8 \%$ moisture content respectively) till 6 months of storage period.

\section{Effect of storage containers of seed storability}

Regarding to storage materials, Padma and Reddy $^{51}$ stated that storability of soybean cultivars could be enhanced by four months 
after storing seed in polythene bag compared to cloth bag. Singh and Dadlani ${ }^{52}$ reported that soybean seeds stored in cloth bag maintained satisfactory germination only for 4 months of storage. Kandil et al., ${ }^{53}$ investigated the response of some soybean cultivars to storage periods, i.e. 3, 6, 9 and 12 months, storage conditions, i.e. ambient conditions and refrigerator conditions at $10 \pm$ $1{ }^{\circ} \mathrm{C}$ as well as storage materials, on germination characters. They concluded that storage Giza 111 cultivar under refrigerator conditions $\left(10 \pm 1^{\circ} \mathrm{C}\right)$ of soybean seed with cloth bags for 3 months enhanced germination properties. A study on wheat seed showed that seeds stored in gunny, cloth and plastic bags were in good moisture content levels and recorded higher germination percentage in comparison with those stored in metal and earthen bins. The packages, depending on its properties, might reduce or obstruct the water vapor exchanges between the seeds and the external environment, keeping the initial water content of the seeds ${ }^{54,55}$.

Recently, Carvalho et al., ${ }^{56}$ in a completely randomized experimental design, used three types of packages (multi-layer paper bag, big bag, and polyethylene container), and five storing periods $(0,2,4,6$ and 8 months) to store soybean seeds. The use of packages with larger amount of seeds (big bag and polyethylene container) did not favor the maintenance of the pre-packing cooling temperature. The types of packages did not show significant differences in the seeds viability during storage, up to eight months, regardless the pre-packing cooling.

In case of niger seed storage, not much information is available. However, its closely related seed, sunflower (Helianthus annuus L.) seed has been studied for seed storage. Udabal et al., ${ }^{57}$ studied the effect of containers and seed treatments on storability of sunflower seeds. The storage experiment comprised of three containers (Vacuum packing, Polythene bag and Cloth bag). Among the containers the seeds stored in vacuum packing recorded significantly higher germination $(84.45 \%)$, hundred seedweight $(4.36 \mathrm{~g})$, root and shoot $(18.05$ and $16.70 \mathrm{~cm})$ length, vigour index (2935) lower electrical conductivity ( $225 \mathrm{dS} \mathrm{m}^{-1}$ ) and seed moisture content $(8.57 \%)$ which was at par with polythene bag. Whereas, lower seed quality parameters were recorded in cloth bag at the end of 11 months of storage period ${ }^{57}$.

The preservation of seed viability and quality in storage is an important trait both for food usage and for seed use. Generally, viability and quality of seeds gradually deteriorate after harvest, but the deterioration in longterm storage depends on environment, biochemical, biological and genetic factors. Changes characterized during the ageing process in seeds include alterations in membrane protein composition ${ }^{58}$, disruption of the nuclear envelope ${ }^{59}$, protein degradation, decreases in lipid content, oxidative stress and decreases in mRNA translation and DNA replication capabilities. Reduced levels of antioxidant enzymes such as superoxide dismutase, catalase and ascorbate peroxidase can also lead to oxidative damage ${ }^{60}$.

Longevity of seed in storage is influenced by the seed quality as well as storage conditions. Storage of seeds with high initial quality will maximize accession longevity. Irrespective of initial seed quality, unfavourable storage conditions, particularly air temperature and air relative humidity, contribute to accelerating seed deterioration during storage. Hence, it is difficult to assess the effective storage period because the storability of the seed is a function of initial seed quality and the storage conditions, and may vary among different seed types ${ }^{61}$. Monitoring viability during storage facilitates timely identification of accessions that require regeneration to 
ensure continued availability of conserved germplasm.

Although seed quality is governed by genetic make-up, but commonly the quality of seeds is deteriorated during storage period. Seed storage and retention of seed viability is always an important consideration in agricultural practice. Poor storage conditions greatly affect seed vigor. The deterioration rate depends on storage condition that is temperature, relative humidity, seed moisture contents, storage container types, etc. Types of container also regulate temperature, relative humidity, and seed moisture contents. High temperature, relative humidity, and moisture in the storage environment appear to be principle factors involved in deterioration of seed quality. As a result, seed health during storage has been found to be influenced by the seed quality.

\section{References}

Ali, Q., Ashraf, M. and Anwar, F., 2009. Physico-chemical attributes of seed oil from drought stressed sunflower (Helianthus annuus L.) plants. Grasas $Y$ aceites, 60(5), pp.477-483.

Al- Yahya, S.A., 2001. Effect of storage conditions on germination in wheat. Journal of Agronomy and Crop Science, 186(4), pp.273-279.

Amable, R.A., R.L. Obendorf. 1986. Soybean seed respiration during simulated preharvest deterioration. J. Exp. Bot. 37:1364-1375.

AOSA, I., 2009. Seed vigor testing handbook. Association of Official Seed Analysts.

Bailly, C., Benamar, A., Corbineau, F. and Come, D., 1998. Free radical scavenging as affected by accelerated ageing and subsequent priming in sunflower seeds. Physiologia Plantarum, 104(4), pp.646-652.

Balešević-Tubić, S., Milošević, M., Zlokolica,
M., Nikolić, Z., Vujaković, M., 1999. Uticaj uslova skladištenja na biohemijske promene u semenu uljanih biljnih vrsta. Procesna tehnika i energetika u poljoprivredi 3(1-2): 2024.

Balešević-Tubić, S., Tatić, M., Miladinović, J., Pucarević, M., 2007. Changes of faty acids content and vigour of sunflower seed during natural aging. Helia 30(47): 61-67.

Bessa, J. F.V., Donadon, J.R., Resende, O., Alves, R.M.V., Sales, J.D.F., Costa, L.M. 2015. Armazenamento do crambe em diferentes embalagens e ambientes: Parte I - Qualidade fisiológica. Revista Brasileira de Engenharia Agrícola e Ambiental, v.19, n.3, p.224-230.

Bhatnagar, P.S., 1990. Technology for increasing soybean production in india. Indian Society of Soil Science; New Delhi.

Cardoso, R.B., Binotti, F.F.S., Cardoso, E.D. 2012. Potencial fisiológico de sementes de crambe em função de embalagens e armazenamento. Pesquisa Agropecuária Tropical, v. 42, n.3, p.272-278.

Carvalho, E.R., Oliveira, J.A, M., Denilson P.D., Silva, H.W.L., Cassiano G.M., 2016. Pre-packing cooling and types of packages in maintaining physiological quality of soybean seeds during storage. Journal of Seed Science, 38(2), 129139.

Clemente, T.E., E.B. Cahoon. 2009. Soybean oil: genetic approaches for modification of functionality and total content. Plant physiol. 151:1030-1040.

Copeland, L.O. and McDonald, M.B., 2001. Seed germination. In Principles of Seed Science and Technology (pp. 72-123). Springer US.

De Oliveira Lins, S.R., de Carvalho, M.L.M., das Graças Cardoso, M., Miranda, D.H. and de Andrade, J., 2014. Physiological, enzymatic, and microstructural analyses 
of sunflower seeds during storage. Australian Journal of Crop Science, 8(7), p.1038.

Delouche, J.C. and Caldwell, W.P., 1960, January. Seed vigor and vigor tests. In Proceedings of the Association of Official Seed Analysts (Vol. 50, No. 1, pp. 124-129). Association of Official Seed Analysts.

Dimberu, G.A., Shamshad, K.B. and Solomon, L., 2015. Quality characterization of Niger seed oil (Guizotia Abyssinica Cass.) produced in Amhara Regional State, Ethiopia. African Journal of Biotechnology, 14(3), pp.171-174.

Duxbury, C.L., Legge, R.L., Paliyath, G. and Thompson, J.E., 1991. Lipid breakdown in smooth microsomal membranes from bean cotyledons alters membrane proteins and induces proteolysis. Journal of experimental botany, pp.103112.

Dwivedi, S., 2014. Germination behaviour of Guizotia abyssinica (L.F.) Cass. (Niger) as influenced by some special treatments. Inter. J. Sudan Res., 4(1), 55-65.

Ellis, R.H., Hong, T.D. and Roberts, E.H., 1991. Seed moisture content, storage, viability and vigour. Seed Science Research, 1(04), pp.275-279.

Ghasemnezhad, A. and Honermeier, B., 2012. Influence of storage conditions on quality and viability of high and low oleic sunflower seeds. International Journal of Plant Production, 3(4), pp.39-48.

Guberac, V., Maric, S., Lalic, A., Drezner, G. and Zdunic, Z., 2003. Hermetically sealed storage of cereal seeds and its influence on vigour and germination. Journal of Agronomy and crop science, 189(1), pp.54-56.

Haithcock, E., Dayani, Y., Neufeld, E., Zahand, A.J., Feinstein, N., Mattout, A.,
Gruenbaum, Y. and Liu, J., 2005. Agerelated changes of nuclear architecture in Caenorhabditis elegans. Proceedings of the National Academy of Sciences of the United States of America, 102(46), pp.16690-16695.

Heatherly, L.G. and Elmore, R.W., 2004. Managing inputs for peak production. Soybeans: Improvement, production, and uses. 3rd ed. Agron. Monogr, 16, pp.451-536.

Hoekstra, F.A., Golovina, E.A. and Buitink, J., 2001. Mechanisms of plant desiccation tolerance. Trends in Plant Science, 6(9), pp.431-438.

Hundertmark, M., Buitink, J., Leprince, O. and Hincha, D.K., 2011. The reduction of seed-specific dehydrins reduces seed longevity in Arabidopsis thaliana. Seed Science Research, 21(03), pp.165-173.

Johnson, R.R. and Wax, L.M., 1978. Relationship of soybean germination and vigor tests to field performance. Agronomy Journal, 70(2), pp.273-278.

Justice, O.L. and Bass, L.N., 1978. Principles and practices of seed storage (No. 506). US Department of Agriculture.

Kandil, A.A., Sharief, A.E. and Sheteiwy, M.S., 2013. Effect of seed storage periods, conditions and materials on germination of some soybean seed cultivars. American Journal of Experimental Agriculture, 3(4), p.1020.

Krishnan, H.B. 2000. Biochemistry and molecular biology of soybean seed storage proteins. J. of New Seeds 2:125.

Kulik, M.M. and Schoen, J.F., 1981. Effect of seedborne Diaporthe phaseolorum var. sojae on germination, emergence, and vigor of soybean seedlings. Phytopathology, 71(5), pp.544-547.

Lee, J., Welti, R., Schapaugh, W.T. and Trick, H.N., 2011. Phospholipid and triacylglycerol profiles modified by PLD suppression in soybean seed. Plant 
biotechnology journal, 9(3), pp.359372.

Martini, S. and Añón, M.C., 2005. Storage of sunflower- seeds: variation on the wax content of the oil. European journal of lipid science and technology, 107(2), pp.74-79.

Mbofung, G.C., Goggi, A.S., Leandro, L.F. and Mullen, R.E., 2013. Effects of storage temperature and relative humidity on viability and vigor of treated soybean seeds. Crop Science, 53(3), pp.1086-1095.

McCormack, J.H., 2004. Seed Processing and Storage: Principles and Practices of Seed Harvesting, Processing, and Storage: and Organic Seed Production Manual for Seed Growers in the MidAtlantic and Sothern US.

McDonald, M.B., 2004. Orthodox seed deterioration and its repair. Handbook of Seed Physiology: Applications to Agriculture, Benech-Arnold, RL and RA Sanchez (Eds.). Food Products Press, New York, pp.273-304.

McGee, D.C., 1995. Epidemiological approach to disease management through seed technology. Annual review of phytopathology, 33(1), pp.445-466.

Morelló, J.R., Motilva, M.J., Tovar, M.J. and Romero, M.P., 2004. Changes in commercial virgin olive oil (cv Arbequina) during storage, with special emphasis on the phenolic fraction. Food Chemistry, 85(3), pp.357-364.

Murthy, U.N. and Sun, W.Q., 2000. Protein modification by Amadori and Maillard reactions during seed storage: roles of sugar hydrolysis and lipid peroxidation. Journal of experimental botany, 51(348), pp.1221-1228.

Murthy, U.N.M., Kumar, P.P. and Sun, W.Q., 2003. Mechanisms of seed ageing under different storage conditions for Vigna radiata (L) WIlczek: lipid peroxidation, sugar hydrolysis, Maillard reactions and their relationship to glass state transition. J. Exp. Bot. 54:1057-1067.

Nagel, M. and Börner, A. 2010. The longevity of crop seeds stored under ambient conditions. Seed Sci. Res. 20:1-12.

Nema, S., Parihar, P. and Raghuwanshi, K.M.S., 2006. Effect of different containers and moisture content on storage fungi of niger seeds.

Nowakowska, J. and Rakowski, K., 2002. Accelerated and natural ageing processes change the properties of plasma membrane in Norway spruce (Picea abies (L.) Karst.) Seeds during storage. Dendrobiology, 47.

Obendorf, R.L., 1997. Oligosaccharides and galactosyl cyclitols in seed desiccation tolerance. Seed Science Research, 7(02), pp.63-74.

Odoba, A., Odiaka, N.I., Gbanguba, A.U. and Bashiru, M., 2016. Germination characteristics of twenty varieties of soybean (glycine max (1) merr stored for seven months. Scientia, 13(3), pp.151155.

Padma V, Muralimohan Reddy B. Seed invigoration for extending storability 331 of soybean seed. Journal of Research Acharya N.G. Range Agricultural University. 2001; 29 (4): 15.

Priestley, D.A., A.C. Leopold. 1983. Lipid changes during natural aging of soybean seeds. Physiologia Plant. 59:467-470.

Ramadan, M.F. and Mörsel, J.T., 2003. Analysis of glycolipids from black cumin (Nigella sativa L.), coriander (Coriandrum sativum L.) and niger (Guizotia abyssinica Cass.) oilseeds. Food Chemistry, 80(2), pp.197-204.

Reuzeau, C. and Cavalie, G., 1995. Activities of free radical processing enzymes in dry sunflower seeds. New phytologist, 130(1), pp.59-66.

Roy, K.W., Baird, R.E. and Abney, T.S., 2001. A review of soybean (Glycine 
max) seed, pod, and flower mycofloras in North America, with methods and a key for identification of selected fungi. Mycopathologia, 150(1), pp.15-27.

Sharma, V.P. 2017. Oilseed Production in India: The Problems and Prospects. Springer.

Siddaramaiah, A.L., Kulkarni, S. and Hegde, R.K., 1980. Effect of weedicides on the growth of Streptomyces sp. Pesticides, 14(6).

Singh, J. Paroha S. and Mishra, R.P., 2016. Effect of Storage on Germination and Viability of Soybean (Glycine max) and Niger (Guizotia abyssinica) Seeds. Int.J.Curr.Microbiol.App.Sci. 5(7): 484491.

Singh, K.K. and Dadlani, M., 2003. Effect of Packaging on Vigour and Viability of Soybean [Glycine max (L.) Merrill] Seed during Ambient Storage. Seed Research-New Delhi-, 31(1), pp.27-32.

Sisman, C.B., 2005. Quality losses in temporary sunflower seed stores and influences of storage conditions on quality losses during storage. Journal of Central European Agriculture, 6(2), pp.143-150.

Sisman, C.B., Delibas, L. and Cicek, G., 2004. Temporary Sunflower Seed Stores and Quality Losses during
Storage. Pakistan Journal of Biological Sciences, 7(5), pp.812-821.

Stewart, R.R.C., J.D. Bewley. 1980. Lipid peroxidation associated with accelerated aging of soybean axes. Plant Physiol. 65:245-248.

Tatipata, A. 2009. Effect of seed moisture content packaging and storage period on microchondria inner membrane of soybean seed. J. Agric. Technol. 5(1): 51-54.

TeKrony, D.M. and Egli, D.B., 1991. Relationship of seed vigor to crop yield: a review. Crop Science, 31(3), pp.816822.

Udabal, N., Hunje, R. and Kote, P., 2014. Effect of containers and seed treatments on storability of sunflower (Helianthus annuus L.). International Journal of Agricultural Sciences, 10(2), pp.774781.

Vertucci, C.W. and Roos, E.E., 1990. Theoretical basis of protocols for seed storage. Plant Physiology, 94(3), pp.1019-1023.

Vertucci, C.W., E.E. Roos. 1993. Theoretical basis of protocols for seed storage II. The influence of temperature on optimal moisture levels. Seed Sci. Res. 3:201213.

\section{How to cite this article:}

Jaya Singh, Seema Paroha and Ravi Prakash Mishra. 2017. Factors Affecting Oilseed Quality during Storage with Special Reference to Soybean (Glycine max) and Niger (Guizotia abyssinica) Seeds. Int.J.Curr.Microbiol.App.Sci. 6(10): 2215-2226.

doi: https://doi.org/10.20546/ijcmas.2017.610.262 